Külgazdaság, LXII. évf., 2018. május-június (3-33. o.)

\title{
Keresetek és képzettségi prémium a külföldi tulajdonú, exportáló feldolgozóipari vállalatoknál Magyarországon SOÓS KÁROLY ATTILA
}

Hazánkban, az Európai Unió egyik gazdaságilag legnyitottabb országában nyilvánvalóan fontos kérdés az, hogy ez a nyitottság hogyan ,bánik” a rendelkezésre álló munkaerövel. Ezt a kérdést vizsgáljuk a feldolgozóiparban a nyitottság két fontos elemének: a vállalatok (részleges vagy teljes) külföldi tulajdonlásának és az exportnak a szempontjából. A kérdés irodalmának áttekintése után ökonometriai eszközökkel vizsgáljuk azt, hogy a külföldi tulajdonlás és az exportértékesités hogyan hat az érintett vállalatokban a dolgozók kereseteire, ideértve azt, hogy a munkaerö magasabb képzettségéhez kapcsolódó bértöbbletet (képzettségi prémiumot) hogyan befolyásolja a vállalatoknál a külföldi tulajdonosi részvétel.*

Journal of Economic Literature (JEL) kódok: F16, F21, F23, F66, J16, J31, R23.

Hazánk az Európai Unió gazdaságilag legnyitottabb országai közé tartozik. Öszszes áru- és szolgáltatásexportunk a cikkünkben elemzett időszak végén, 2011-ben elérte a bruttó hazai termék (GDP) 86,7 százalékát. Ennél magasabb hányadot csak néhány, hazánknál kevesebb lakosú (Írország, Szlovákia) vagy összehasonlíthatatlanul kisebb népességü ország (Luxemburg, Málta) esetében találunk. A nyitottság egy másik alapvető fontosságú mutatója szerint a beáramlott közvetlen külföldi beruházások összesített állományának a GDP-hez viszonyított arányában pedig - a

* Az írás korábbi változataihoz tett javaslataikért, megjegyzéseikért köszönettel tartozom Fertő Imrének, Halpern Lászlónak, Köllö Jánosnak, Lackó Máriának, Oblath Gábornak, a névtelen lektornak és Varga Júliának. Természetesen minden megmaradt hibáért engem terhel a felelősség.

https://doi.org/10.47630/KULG.2018.62.5-6.3

Soós Károly Attila, az MTA KRTK Közgazdaság-tudományi Intézet ny. tudományos fömunkatársa. E-mail: soos.karolyattila@krtk.mta.hu 
2012-es adatok szerint ${ }^{1}$ - 80,6 százalékkal a nyolcadikak vagyunk a 27 tagállam között.

A nyitottság kapcsán minden bizonnyal az egyik legfontosabb kérdés: hogyan „bánik” ez a hazai gazdaságban rendelkezésre álló munkaerővel. Persze ez a kérdés igencsak szerteágazó. Hiszen a nyitottság a külföldi munkavállalás lehetőségét és mára meglehetősen elterjedt gyakorlatát is magában foglalja, valamint az áru- és szolgáltatásimportnak is vannak fontos munkaügyi hatásai. E cikkben azonban csak a nyitottság már említett két fontos elemével: az exporttal - az exportáló vállalatokkal - és a közvetlen külföldi beruházásokkal - a (részben vagy teljesen) külföldi tulajdonú vállalatokkal - foglalkozunk. Azt elemezzük, hogy a külföldi tulajdonosi részvételü és/vagy exportáló vállalatokban a bérek és fizetések hogyan alakulnak a belföldi tulajdonú, belföldi piacot kiszolgáló vállalatok hasonló mutatóihoz képest. Vizsgáljuk emellett azt is, hogy a munkaerő magasabb képzettségéhez kapcsolódó bértöbblet (képzettségi prémium) hogyan alakul a külföldi tulajdonosi részvételü vállalatcsoportban a többi vállalathoz képest. Először a következő részben feltett kérdéseink irodalmát tekintjük át, ezután a felhasznált adatokat és az ökonometriai megközelítést mutatjuk be. Majd a becslési eredményeket közöljük és elemezzük, a cikk végén a következtetéseinket találja az Olvasó.

\section{Irodalmi áttekintés}

A vállalati dolgozók keresetei alakulásának hatalmas irodalma van, és speciális témánk tárgyalása, vizsgálata során nem feledkezhetünk meg a kereset alakulásának az irodalomban kiterjedten tárgyalt általános tényezőiről.

A keresetek általános tényezői

Ilyen tényezők a képzettség, a munkahely területi elhelyezkedése, a vállalati méret (a nagyobb vállalatoknál általában magasabbak a keresetek) és a nem (a férfiak keresete általában magasabb). Ami a képzettséget illeti, annak két eleme különböztethető meg: a formális (iskolai, egyetemi) képzettség és a munkában szerzett tapasztalat, többletképzettség, és utóbbit a munkában töltött évekkel mérik. Az utóbbiaktól való függés azonban fordított U alakú, mert idősebb korban, főleg a fizikai

\footnotetext{
1 Az adatok forrása: Eurostat.
} 
Keresetek és képzettségi prémium a külföldi tulajdonú, exportáló...

erőfeszítést is követelő területeken a teljesítmény és vele a kereset általában csökkenő tendenciát mutat (Mincer, 1958). A kereseti egyenletben ezt a kettősséget úgy célszerü tükröztetni, hogy a (pozitív koefficiensünek várt) munkában töltött évek száma mellett ennek négyzetét is bevesszük a független változók közé (és a koefficiensét negatív előjelünek várjuk). Az egyenlet kialakítása szempontjából érdektelen, de a közgazdasági értelmezés szempontjából fontos, hogy a kereseteknek a munkában töltött évekkel összefüggő növekedése az ún. hatékonysági bérezési irányzat egyes képviselői szerint csak részben függ össze a szakképzettség növekedésével. Például Lazear-Moore [1984] kimutatja, hogy az alkalmazásban állók keresete a munkában töltött évekkel összefüggésben meredekebben emelkedik, mint a velük azonos szakmában dolgozó önfoglalkoztatóké. És hozzáteszi: semmi alapunk sincs azt gondolni, hogy ez a különbség a termelékenység időbeni növekedésének eltéréséből adódik. A szerzők következtetése az, hogy az alkalmazásban állók keresetének gyors időbeni növekedése sajátos ösztönző: a későbbi kompenzáció (implicit) ígéretével sarkall eleinte viszonylag alacsony kereset mellett is olyan jó és sok munkára, amellyel a dolgozó elkerüli az elbocsátást.

\section{Külföldi tulajdonlás és export: kereseti prémium}

A (teljesen vagy részben) külföldi tulajdonú vállalatok, továbbá az exportra termelő vállalatok a belföldi tulajdonúban levőknél, illetve a belföldi piacra termelőknél többnyire magasabb (,„prémiumokkal” megnövelt) béreket fizetnek.

Mind a (részben) külföldi tulajdonú, mind az exportáló vállalatokban fizetett magasabb béreket általában részlegesen megmagyarázzák az előzőekben említett általános tényezők. Így például a vállalatok, ha külföldi tulajdonúak és/vagy exportra termelnek, akkor gyakran több magasabb szakképzettségü és így jobban megfizetett munkaerőt foglalkoztatnak, valamint az egyes országokon belül gyakran a fejlettebb, az átlagosnál eleve magasabb kereseteket biztosító (és az egyes vállalatoktól ilyeneket meg is követelö) régiókban helyezkednek el (Peluffo, 2001, Zulfiu-Alili, 2014, Hale-Long, 2013, Hosein-Tewarie, 2005, Zhang-Zhang, 2003, Hunya, 2014, Damijan-Kostevc, 2011). A külföldi és/vagy exportáló vállalatok az átlagosnál többnyire nagyobb méretüek, és általában ez is emeli a bérszínvonalat. Ez utóbbit, ha csak részlegesen is, az magyarázza, hogy a nagyobb vállalatoknál általában magasabb a tőkeintenzitás és a munka termelékenysége, továbbá gyakoribb a dolgozók szakszervezeti tagsága (Brown-Hamilton-Medoff, 1990, Kalleberg-Van Buren, 1996, Lipsey-Sjöholm, 2004). A legtöbb kutatás - köztük e cikk hivatkozásainak túlnyomó 
része - szerint azonban a (részleges vagy teljes) külföldi tulajdonnal és az exportőr státusszal mindezeken túlmenő bérprémium is együtt jár. (Megemlíthető például Earle-Telegdy [2008] munkája a külföldi tulajdonlás hatásáról a magyar feldolgozóipari bérekre.) Külön-külön méri a külföldi tulajdon és az export hatását a kanadai feldolgozóipari bérek elemzésénél Breau-Brown [2011] tanulmánya. Vállalati szintü becslésük az exportőr státuszra 15, a külföldi tulajdonos többségi szerepére 30 százalékos kereseti többletet jelez. Ha az egyenletbe a vállalati létszámot, a tőke/munka arányt, a városi vagy vidéki elhelyezkedést, az alkalmazottak átlagos képzettségét és életkorát is beveszik, akkor a kétféle kereseti többlet 7-10, illetve 15-20 százalékra csökken. Ha pedig a becslés a vállalatok helyett az egyes alkalmazottak szintjén történik, az további csökkenéssel jár, de a koefficiensek pozitívak maradnak. Greaney$L i$ [2013] a (Sanghajt és két másik nagyvárost magában foglaló) Jangce-delta gépés berendezésgyártó ipari és textilipari vállalatainak kereseti viszonyait elemzik. Megállapítják, hogy az ágazatra, az elhelyezkedésre, a tőkeintenzitásra, a vállalati méretre, a munkaerő-állomány sajátosságaira és az exportőr státuszra kontrollálva a hongkongi, a makaói és a tajvani tulajdonú cégek a gép- és berendezésgyártásban 18, a textiliparban 11 százalékkal többet fizetnek, mint a belföldi tulajdonú magánvállalatok. Más külföldi tulajdonú vállalatok esetében a prémium nagyobb: 36, illetve 15 százalék. Az exporthoz kapcsolódó kereseti prémium ennél kisebb: a két ágazatban rendre öt, illetve hat százalék. Girma-Greenaway-Wakelin [2001] az 1990-es évek első felében az Egyesült Királyság feldolgozóiparában végzett kutatás alapján azt találja, hogy a külföldi tulajdonú vállalatoknál a munka termelékenysége átlagosan 10 százalékkal magasabb: a bérek még ezt leszámítva is 5 százalékkal meghaladják a belföldi tulajdonú vállalatok által fizetett értéket.

Girma-Greenaway-Wakelin [2001] azt is kimutatják, hogy az Egyesült Királyságban a külföldi tulajdonú vállalatok által fizetett keresetek nemcsak magasabbak a belföldi tulajdonúak által fizetetteknél, hanem gyorsabban is emelkednek azoknál - de csak a termelékenység gyorsabb növekedésével arányosan. A probléma - ritka - dinamikus megközelítésének egy másik példája Lipsey-Sjöholm [2006]. A szerzők elemzése szerint Indonéziában a külföldiek általában az átlagnál valamivel magasabb kereseteket biztosító cégeket vesznek, és utána az átlagnál gyorsabban emelik a béreket.

A vállalatok (részleges) külföldi tulajdonlásával és exportőr státuszával összefüggő kereseti prémium ilyen, a tanulmányok szerzői által megfigyelt tényezőkkel nem megmagyarázható részével kapcsolatban felvethető a következő kérdés. Miért van egyáltalán ez a prémium, mi indítja a vállalatokat arra, hogy ezt kifizessék. Az 
Keresetek és képzettségi prémium a külföldi tulajdonú, exportáló...

irodalom erre kétféle magyarázatot ad. Egyrészt nem megfigyelhető képzettségről (képzettségi többletről) szólnak, másrészt járadékmegosztásról: az exportáló, illetve az anyaországukon kívül is beruházó vállalatok többletjövedelmének ${ }^{2}$ az alkalmazottakkal való megosztásáról (Villarreal-Sakamoto, 2011 és Macis-Schivardi, 2016). A járadékmegosztási feltevést Villarreal-Sakamoto [2011] magyarázzák meg alaposabban. Érvelésüket arra alapozzák, hogy ha külföldi vállalatok szegényebb országokban végeznek beruházásokat, azzal - úgymond kizsákmányolóként - politikai támadásoknak teszik ki magukat, amelyek ellen védekezniük kell, ${ }^{3}$ aminek jó módja a magas bérek fizetése. Ezt a magyarázatot egy bizonyos szempontból alátámasztani látszik a szerzők azon (mexikói) megfigyelése, hogy a bérprémium nagysága függ a külföldi beruházó nemzeti hovatartozásától: a gazdagabb ország beruházói nagyobb prémiumot fizetnek. Csakhogy a külföldi beruházók általában a gazdag országokban is - a már említett Egyesült Államokon kívül például Franciaországban (Carluccio-Fougere-Gautier, 2014), Nagy-Britanniában (Girma-Greenaway-Wakelin, 2001), Németországban (Gelübcke-Philipp, 2013) és Japánban (Kyoji-Murakami, 2005) - is fizetnek kereseti prémiumot, erre pedig aligha lehet ráhúzni a kérdéses magyarázatot. Marad a magyarázat másik ága: az, hogy a külföldi tulajdonú és/vagy exportáló vállalatok dolgozóik nem megfigyelhető - sem iskolai végzettségükben, sem munkában töltött éveik számában nem megjelenő - képzettségi többletét javadalmazzák magasabb keresetekkel, és nem is veszik alkalmazásba a kisebb kereseti igénnyel jelentkezőket, akikben kevésbé képzett munkavállalókat látnak. (Ezzel gyakran foglalkozik az irodalom, a kínai mérnökök esetéröl lásd például: HaleLong, 2013). Ilyen fajta vállalati viselkedést ír le a munkapiac-kutatás hatékonysági bérezési irányzatát követő egyik elemzés. Akerlof-Yellen [1986] rövid jellemzése szerint „Ha a dolgozók felkészültsége és minimálisan elvárt keresete pozitív öszszefüggésben van egymással, akkor a jobban fizető vállalatok felkészültebb jelölteket alkalmaznak. ...Egy ilyen modellben minden vállalat hatékonysági bért fizet, és optimális módon elutasítja azokat jelentkezőket, akik ennél a bérnél kevesebbért ajánlkoznak munkára.”

Az export és a (részleges) külföldi tulajdonlás keresetekre gyakorolt hatását ritkán találják egyformának a foglalkoztatottak különféle csoportjai esetében. Az ilyen kivételek közé tartozik Carluccio-Fougere-Gautier [2014] franciaországi külföl-

\footnotetext{
${ }^{2}$ Az ilyen többletjövedelmek diszkussziójáról lásd: Amiti-Davis [2011], Egger et al. [2015] és Helpman et al. [2010].

3 „A Mexikóhoz hasonló fejlődő országokban müködő nagy nemzetközi vállalatok erősen ki vannak téve helyi politikai vezetők és otthoni dolgozói jogi aktivisták olyan vádjainak, hogy kizsákmányolják dolgozóikat és rosszul bánnak velük" (Villarreal-Sakamoto, 2011, 894. o.)
} 
di beruházásokról szóló írása. Általános szabálynak ezzel szemben az tűnik, hogy noha az alacsonyabb képzettségü alkalmazottak is kapnak prémiumot, a magasabb képzettségűek prémiuma nagyobb mértékủ. Emellett gyakran látjuk azt is, hogy a férfiak kereseti prémiuma a nőkénél nagyobb.

Egy 2001. évi 1500 vállalatra kiterjedő kínai világbanki felmérés adatai alapján Hale-Long [2013] úgy találják, hogy a külföldi tulajdonú vállalatokban a munkások 17, a mérnökök 34 százalékkal keresnek többet, mint a helyi tulajdonú magánvállalatokban. Kínánál maradva, $W u$ [2001] és Zhao [2001] is a magasabb végzettséggel járó magasabb kereseti prémiumot ír le. Ami a nemek közötti megkülönböztetést illeti, a külföldi beruházások kínai liberalizálásának első szakaszában még csak főleg nőket foglalkoztató, egyszerübb műveletekre szakosított üzemeket nyitottak, és ezzel főleg a női munkaerőt drágították meg (a helyi vállalatok számára is). Később (2000 után) már a szakképzett férfi munkaerőt keresték és fizették meg inkább (Braunstein-Brenner, 2007). Egy Macedóniában 2008-ban végzett felmérés eredményei alapján a férfiak körében a külföldi tulajdonú vállalatoknál foglalkoztatottak kereseti prémiuma 45 százalék, a nőknél csak 12 százalék volt (és itt a koefficiens nem is volt szignifikáns). Szellemi foglalkozás esetén mindkét nemnél további, több mint 20 százalék prémium adódik. Zulfiu-Alili [2014] szerint az ilyen prémium technológiai és termelékenységi különbségekkel hozható összefüggésbe.

Az exporttal járó (vagy nem járó) kereseti prémium problémájának elemzésénél figyelmet kell fordítani az export tartósságának kérdésére. Fertö-Soós [2009] országok és azok egyes termékei szintjén, Békés-Muraközy [2012] vállalatok szintjén úgy találták, hogy a tartósabb export magasabb GDP-vel, illetve kedvezőbb vállalati gazdálkodási eredménnyel párosul. Ezért meg kell vizsgálni, hogy a tartósabb vállalati export a dolgozók magasabb keresetével jár-e együtt.

Ellenpéldák: amelyekben a külföldi tulajdonlás és/vagy az export hatása a keresetekre negativ vagy semmilyen

A külföldi tulajdonlás és az exporttevékenység pozitív kereseti hatása a fejlett és a kevésbé fejlett országokban nem mindig érvényesül. A fejlett országokat illetően utalni kell Feliciano-Lipsey [2006] cikkére, amely szerint az Amerikai Egyesült Államokban a külföldi tulajdonú vállalkozások a belföldieknél általában ugyan magasabb kereseteket fizetnek, de kivételt képeznek e szabály alól a magas szintü szakképzettséget igénylő ágazatok. A szerzők szerint ennek oka vélhetően az, hogy ezekbe az ágazatokba a külföldi beruházók azzal a céllal fektetnek be, hogy elsajá- 
Keresetek és képzettségi prémium a külföldi tulajdonú, exportáló...

títsák az amerikai technológiát, tehát nem a saját technológiájukat viszik oda. Heyman-Sjöholm-Tingvall [2007] az egész svéd feldolgozóiparra kiterjedő elemzése azt találja, hogy csak a zöldmezős külföldi beruházásoknál van - szerény mértékü - kereseti prémium. Ezzel szemben, ha külföldi kézbe kerül egy svéd vállalat, az általában nem pozitívan - néha éppen negatívan - hat a keresetekre.

Kevésbé fejlett vagy kifejezetten szegény országokban még inkább előfordulnak olyan helyzetek, amelyekben a vállalatok külföldi tulajdonlása és/vagy exportőr státusza nem jár együtt pozitív kereseti prémiummal, vagy éppen negatív „prémiummal” jár. Itt említhető három olyan cikk, amelyek különböző országok exportját elemzik célországok szerinti bontásban. Az egyik (Rankin-Schöer, 2013) azt találja, hogy a Dél-Afrikai Köztársaságban csak az igényesebb piacokra exportáló vállalatok fizetnek pozitív értékü exportprémiumot tartalmazó kereseteket; a kevésbé igényes piacú (szomszédos) országokba irányuló export negatív prémiummal jár. A második cikk (Milner-Tandrayen, 2007) több dél-afrikai ország adatainak elemzése alapján, a harmadik (Aydiner-Avsar, 2014) a török iparban az előbbieknek pontosan a fordítottját találja: azt, hogy a szegényebb országokba irányuló export jár pozitív kereseti prémiummal, és a gazdagabb országokba irányuló exportnál nincs ilyen. (Ezek az írások a magyarázatban nem a piacok relatív igényességét, hanem a gazdagabb országok piacán mutatkozó erősebb, az eladási árakat lefelé nyomó versenyt hangsúlyozzák.) Tomohara-Yokota [2011] thaiföldi kutatása szerint a külföldi tulajdonú vállalatoknál általában van kereseti prémium, kivéve a japán és tajvani tulajdonúakat, amelyeknél többnyire alacsony képzettségü munkaerőt foglalkoztatnak egyszerü feladatokkal. A mi kutatásunk azonban az exportot nem bontja szét célországok, célországcsoportok szerint, erre adataink nem adnak lehetőséget.

Számunkra így érdekesebbek más olyan „kivételek” a külföldi tulajdonláshoz, az exporthoz kapcsolódó magasabb dolgozói keresetek „szabálya” alól, amelyeket a gyöngébben fejlett országok sajátos helyzetéhez, problémáihoz kapcsol az irodalom. E körbe tartoznak azok az - a mindig szük, speciális területekre korlátozott elemzés alapján készült - írások, amelyek a termelési folyamatok egyes részeinek a gyöngébben fejlett vagy szegény országokba történő kihelyezésének (azaz a szegény országok nemzetközi termeléshálózatokba való bekapcsolásának) hatását a foglalkoztatottak helyzetére, jövedelmeire kifejezetten és erősen hátrányosnak mutatják. Anner [2011] például a közép-amerikai országokba (föleg az Egyesült Államokból) kiszervezett ruházati ipari tevékenység alapos vizsgálatával kimutatja, hogy ez három okból csökkentette a kereseteket a hagyományos, integrált gyártást folytató vállalatokban 
fizetett bérekhez képest. Egyrészt a gyártási folyamat és vele a munkaerő országok közötti szétszórtsága csökkenti a sztrájkok hatékonyságát, másrészt az alacsony beruházási költségek miatt komoly fenyegetést jelent az, hogy a tevékenység könnyen átvihető más vállalatba, más városba, országba. Harmadrészt - amennyiben a tevékenységet helyi tulajdonú vállalatban, nem pedig a tevékenységet kiszervező cég leányvállalatában végzik - a költségeken belül magasra emelkedik a bérköltség súlya, és így a vezetés számára különösen fontossá válik annak korlátozása.

Ez a leírás erősen emlékeztet a magyar ruházati ipar és más könnyüipari területek bizonyos szegmenseinek helyzetére a korai 1990-es években. Akkor az olcsó import megjelenése és a szovjet piac elvesztése miatt ezekben az ágazatokban az ún. bérmunkáztatás - egyszerübb munkafolyamatok elvégeztetése nyugat-európai országok gyáraiban készülö termékeken - igen elterjedt volt nálunk. Tudjuk, hogy ezt a tevékenységet később túlnyomó részben a tőlünk keletebbre lévő országokba telepítették át. A továbbiakban megvizsgáljuk, mi maradt meg nálunk a bérmunkáztatásból, illetve a vele járó keresetcsökkentő hatásból. Emellett, ugyancsak az 1990es években megjelentek olyan közgazdasági elemzések, amelyek a közép-európai országok nemzetközi termelési láncokba való bekapcsolódásának az itt leírtakhoz többé-kevésbé hasonló degradáló, a kereseteket lefelé nyomó „modelljét” általánosabb érvénnyel, a könnyüiparon kívüli területekre is - az egész feldolgozóiparra - vizionálták. Gabrisch-Werner [1998], Aturupane-Djankov-Hoekman [1999], Egger-Stehrer [2001] kutatásai például azt találták, hogy Csehországban, Magyarországon és Lengyelországban 1993-1999 között a félkész termékeknek az akkori Európai Unióból való behozatala és oda irányuló exportja - más szóval ezen országoknak a bekapcsolódása a nemzetközi termelési láncokba - negatív hatással volt a képzettségi prémiumra.

Ismeretesek azonban az idézetteknek ellentmondó kutatási eredmények is. Alfaro-Charlton [2009] rámutat arra, hogy a csúcstechnológiás iparok vállalatai általában csak csúcstechnológiás beruházásokat valósítanak meg külföldön (is), egyéb félkész termékeket inkább más vállalatoktól vásárolnak. Márpedig csúcstechnológiás vállalatok sok beruházást valósítottak és valósítanak meg Kelet-Közép-Európában. Lorentowicz-Marin-Raubold [2005, 1. o.] osztrák-lengyel ipari kapcsolatokat vizsgáló kutatásai pedig arra az eredményre vezetnek, hogy „az Európában kialakulóban lévő új nemzetközi munkamegosztással a magas jövedelmű Ausztria az értéklánc alacsony szakképzettségigényű részére; míg az alacsony jövedelmü Lengyelország pedig a magas szakképzettségigényü részre szakosodik". 
Keresetek és képzettségi prémium a külföldi tulajdonú, exportáló...

E szerzők azt is kimutatják, hogy ilyen folyamatok eredményeképpen a képzettségi bérprémium növekedett Lengyelországban és csökkent Ausztriában. Itt kell utalnunk arra is, hogy Kézdi [2002] Magyarországon az 1990-es évek közepe után növekvő képzettségi bérprémiumot talál.

\section{Az adatok}

Az általunk használt adatbázis két forráson alapul. Az egyik a társasági adóról és az osztalékadóról szóló 1996. évi LXXXI. törvény értelmében társasági adóbevallásra kötelezett vállalatoknak a mérleg- és eredménykimutatásból származó, a Nemzeti Adó- és Vámhivatal által összeállított adatait tartalmazza. A másik forrás a Nemzeti Munkaügyi Hivatal éves harmonizált bértarifa-felvétele, amely munkavállalói megfigyeléseket tartalmaz, és a munkavállalók képzettségéről, koráról, neméről és (május havi) keresetéről, annak elemeiről ad részletes információt. A bértarifafelvétel célsokasága bizonyos mérethatár fölött az összes vállalat véletlenszerüen kiválasztott dolgozói, bizonyos mérethatár alatt a vállalatok egy véletlen mintájának összes dolgozója. A felvétel reprezentatív, évente 100-220 ezer munkavállalói megfigyelést végeznek. A két adatbázis összekapcsolható, az összekapcsolást és az adatok felhasználásra való előkészítését az MTA Közgazdaság- és Regionális Tudományi Kutatóközpontjának Adatbankja végezte. Az adatok összeállításában és kezelésében Czethoffer Éva és Czeglédi Tibor volt segítségemre. Az adatbázis a 2002-2011 évekre tartalmazza a kutatásunkhoz szükséges adatok teljes körét. Némi kompromisszummal - a dolgozók szakszervezeti tagságára és jelenlegi vállalatuknál eltöltött idejére vonatkozó adatokról lemondva - a becslések nagyobb részében vissza tudunk menni 2000-ig. (A panelbecsléseknél erre a dolgozók azonosításához szükséges adatok hiányosságai miatt nincs lehetőség.)

A kutatást az élelmiszeripar nélküli feldolgozóiparra (a 2003-as TEÁOR szerint a 17-36, a 2008-as szerint a 13-32 ágazatokra) korlátoztuk. Az élelmiszeripart azért zártuk ki, mert tevékenységének sajátos és erős szezonalitása miatt exportteljesítményét nem lehet dolgozóinak májusi keresetével összekapcsolni. Ugyanez az alapja a mezőgazdaság kizárásának is. Az adatbázis lehetőséget adna arra, hogy a kisebb (például a 10 vagy 20 főnél kevesebbet foglalkoztató) vállalatok adatai nélkül számoljunk. Ezt az indokolná, hogy (a hozzáértők konszenzusa szerint) a statisztikai megfigyelést erősen torzító adócsalásfajtának, a „zsebbe fizetésnek” a 10 főnél többet foglalkoztató vállalatoknál csak marginális szerepe van. Azonban az ilyen 
módon a nagyobb vállalatokra korlátozott számítások nem adtak érdemlegesen más eredményeket, ezért eredményeik közlésétől eltekintünk.

A dolgozók reprezentatív megfigyelése folytán az egyes megfigyelt munkavállalók egy-egy kisebb vagy nagyobb csoport képviselői, tehát adataikhoz súlyok kapcsolódnak. Ennek következtében az outlier egyedek keresésének megszokott módszereit nem tudtuk alkalmazni. Ehelyett (az értelmetlen, mert adathiányos megfigyeléseken kívül) minden évben elhagytuk azokat a megfigyeléseket, amelyeknél a bér az adott év átlagának 30 százalékánál kisebb vagy 500 százalékánál nagyobb. A szélsőséges értékek ilyen levágása „alulról” 2965-tel, „felülről” 5403-mal csökkentette az adatbázis sorainak számát, a számítások alapját képező, megmaradt megfigyelések száma súlyozás nélkül 334 437, súlyokkal 3924 048, azaz évi átlagban 27870 , illetve 327004.

Az így kialakított adatbázisunk 12 évében összesen 5798 vállalat szerepel, évente átlagosan 1644. 1939 vállalat csak egy, 1324 csak két évben szerepel; mind a 12ben 184, 11-ben 154, 10-ben 111. A vállalatok közül 1806 (31,1 százalék) egyáltalán nem exportált, 220 (3,7 százalék) több mint 99 százalékban exportra értékesített. A 12 év alatt az exportértékesítési hányad súlyozatlan átlaga 28,1 százalék, a súlyozott átlag (az összes exportárbevétel aránya az összes bevételhez) 70,8 százalék volt, tükrözve azt, hogy a nagyobb vállalatok általában erősebben exportorientáltak. A vállalatok közül 1015 (17,5 százalék) volt 99,5 százalék fölötti arányban külföldi tulajdonú, 4026-nak (69,4 százaléknak) nem voltak külföldi tulajdonosai. Az időszak átlagában 1411 vállalat (24,3 százalék) volt többségi külföldi tulajdonban. Az időszak folyamán 381 vállalatnál (6,6 százalék) figyelhettük meg a belföldi és a külföldi tulajdonosi arány változását. Közülük 197-nél történt váltás a belföldi és a külföldi többségi tulajdonos között.

A változók a következőket jelentik:

- exporthányad - a vállalati export- és teljes árbevétel hányadosa,

- képzettségi színvonalat jelző álváltozók (alap a szakmunkásképző-végzettség):

- d_legf8oszt - legfeljebb nyolcosztályos általános iskolai végzettség;

- d_szakiskola-szakiskola,

- d_szakközépisk-szakközépiskola,

- d_gimnázium - gimnázium,

- d_technikum - technikum,

- d_föiskola - föiskola, alapfokozat,

- d_egyetem - egyetem, mesterfokozat. 
Keresetek és képzettségi prémium a külföldi tulajdonú, exportáló...

- kereset, tisztított kereset - tisztított (családi pótléktól és más nem munkajövedelmektől megtisztított) kereset forintban, logaritmikus formában használjuk,

- munkatapasztalat - a dolgozó által munkában töltött évek (az életkor 6 év tanulással csökkentve),

- munkatap. négyzete - az előző mutató négyzete,

- külftöbbs_nem - a többségi külföldi tulajdont jelző és a dolgozó nemét jelző álváltozók szorzata,

- külftöbbstulajdonos - álváltozó, értéke 1, ha a jegyzett tőke többsége külföldi tulajdonban van, egyébként nulla,

- a többségi külföldi tulajdon és a képzettség kereszthatását jelző álváltozók (a többségi külföldi tulajdont jelző és a megfelelő képzettségi szintet jelző álváltozók szorzatai):

- d_külft*legf8oszt,

- d_külft*szakiskola,

- d_külft*szakközépisk.,

- d_külft*gimnázium,

- d_külft*technikum,

- d_külft*föiskola,

- d_külft*egyetem.

- In_létszám - vállalati létszám, fö - logaritmikus formában használjuk,

- nem - a dolgozó neme, 0 , ha nő, 1 , ha férfi,

- régiók szerinti elhelyezkedés álváltozói a vállalat székhelye alapján:

- Közép-, Ny.-Dunántúl - 1, ha a vállalat székhelye a Közép- vagy Nyugat-dunántúli Régióban van, egyébként 0 .

- Központi Régió - 1, ha a vállalat székhelye a Központi Régióban van, egyébként 0 .

- In_term_ség - a munka termelékenysége a vállalat egy dolgozójára jutó árbevétel forintban, logaritmikus formában használjuk,

- ujbelépő - értéke egy, ha a dolgozó az elöző évben lépett be a vállalathoz, egyébként nulla.

A használt változók közötti legfontosabb korrelációs koefficienseket az 1. táblázat tartalmazza. 


\section{A főbb változók közötti korrelációs együtthatók értékei}

\begin{tabular}{|c|c|c|c|c|c|}
\hline Megnevezés & $\begin{array}{l}\text { kereset lo- } \\
\text { garitmusa }\end{array}$ & In_létszám & ln_term_seg & exportarány & $\begin{array}{l}\text { munkata- } \\
\text { pasztalat }\end{array}$ \\
\hline kereset logaritmusa & 1 & & & & \\
\hline ln_létszám & 0,23 & 1 & & & \\
\hline ln_term_ség & 0,5 & 0,39 & 1 & & \\
\hline exportarány & 0,18 & 0,59 & 0,24 & 1 & \\
\hline munkatapasztalat & 0 & $-0,08$ & $-0,09$ & $-0,11$ & 1 \\
\hline
\end{tabular}

Megjegyzés: A dőlt, félkövér betűs együtthatók szignifikánsak egyszázalékos szinten.

A független változók közül a létszám és a termelékenység között figyelhetünk meg olyan korrelációt, amelyet már biztosnak, de még gyöngének szoktunk minősíteni: ez a korreláció nem éri el azt a mértéket, amely a kollinearitás problémáját vethetné fel.

A becslésekben a felsorolt változókon kívül szerepeltek - de a becslési eredmények táblázataiban nem kerülnek bemutatásra - álváltozók az évekre (a 12 év közül az első 11-re: 2000-től 2010-ig) és a következő (a 2003-as és 2008-as TEÁOR szerinti, részben összevont) ágazatokra: textilgyártás, ruházati ipar, bőrfeldolgozás, fafeldolgozás, papíripar, nyomdai tevékenység, koksz- és kőolajipar, gyógyszergyártás és más vegyipar, gumi, müanyag termék gyártása, nemfém ásványipar, kohászat, fémfeldolgozás, gép és berendezés gyártása, villamos gépipar, müszer-, számítógépgyártás és optikai ipar, közútijármü-gyártás, más jármügyártás, bútorgyártás, álváltozó nélkül szerepel az egyéb ipar.

\section{Ökonometriai megközelítés}

Van az adatbázisunknak egy az ökonometriai lehetőségeinket igencsak korlátozó vonása: a súlyok jelenléte. Az ökonometriai programcsomagok - köztük az általunk használt Stata - (gyakorisági) súlyokkal csak állandó hatásos (fe) becslést engednek meg. Az ilyen becslés az időben állandó független változókat beleviszi az állandó hatásba. Ez - mondhatjuk így - két dolgot jelent. Egyrészt ezzel a módszerrel nem 
Keresetek és képzettségi prémium a külföldi tulajdonú, exportáló...

tudjuk vizsgálni olyan tényezőknek a függő változóra való hatását, amelyek az időben nem változnak. A mi esetünkben a külföldi és a belföldi többségi tulajdon között - mint már említettük - csupán 197 vállalatnál, az összes vállalat 3,4 százalékánál történik váltás 2000-2011 között. Panelbecslést tehát csak erre a szük vállalati körre tudunk alkalmazni. Ezt azonban érdemes is megtennünk, mert ez a módszer a nem ismert, nem azonosítható állandó tényezőket is beleviszi az állandó hatásba. Ezzel „automatikusan” kontrollál rájuk, amire egyébként - nem azonosítható tényezőkről lévén szó - nem lenne más módunk. A vállalatok szélesebb körére persze csak OLSbecslést tudunk végezni.

A panelbecsléshez szükség van az azonos, különböző években megfigyelt dolgozók azonosítására. Erre csak a munkahelyet nem változtatóknál (legalább két évben ugyanott dolgozóknál) van lehetőség, akik az összes dolgozó körülbelül 70 százalékát teszik ki. Öket egyértelmüen azonosítani tudtuk a rendelkezésre álló adataik - a vállalatukon kívül születési évük, születési hónapjuk, képzettségük és foglalkoztatási kódjuk - alapján, azaz csekély eltéréssel az Earle-Telegdy [2008] és Reizer [2017] által alkalmazott megoldástól.

\section{Becslési eredmények}

A külföldi tulajdonlás és az exportértékesités mint a keresetet meghatározó tényezök elemei

2. táblázat

\section{A keresetet meghatározó tényezők becslései}

(OLS-becslés robusztus sztenderd hibákkal)

Függő változó: a tisztított kereset logaritmusa

\begin{tabular}{lccccc}
\hline Független változó & & Összes vállalat & & $\begin{array}{c}\text { Legalább 10\%-os } \\
\text { külföldi többségi } \\
\text { tulajdonhányadú } \\
\text { vállalatok }\end{array}$ & $\begin{array}{c}\text { Változóan kül- } \\
\text { vagy belföldi } \\
\text { többségi tulajdon- } \\
\text { hányadú vállalatok }\end{array}$ \\
\hline 1 & 2 & 3 & 4 & 5 & 6 \\
\hline külftöbbstulajdonos & 0,16 & 0,11 & 0,08 & 0,08 & 0,08 \\
nem & 0,14 & 0,14 & 0,15 & 0,21 & 0,20 \\
külftöbbs*nem & 0,07 & 0,07 & 0,05 & $-0,02$ & $-0,02$
\end{tabular}




\begin{tabular}{|c|c|c|c|c|c|}
\hline Független változó & \multicolumn{3}{|c|}{ Összes vállalat } & $\begin{array}{l}\text { Legalább } 10 \% \text {-os } \\
\text { külföldi többségi } \\
\text { tulajdonhányadú } \\
\text { vállalatok }\end{array}$ & $\begin{array}{l}\text { Változóan kül- } \\
\text { vagy belföldi } \\
\text { többségi tulajdon- } \\
\text { hányadú vállalatok }\end{array}$ \\
\hline 1 & 2 & 3 & 4 & 5 & 6 \\
\hline exporthányad & & 0,13 & 0,05 & 0,05 & 0,12 \\
\hline ln_létszám & & & 0,03 & 0,00 & $-0,01$ \\
\hline ln_term_ség & & & 0,10 & 0,10 & 0,16 \\
\hline munkatapasztalat & 0,02 & 0,02 & 0,02 & 0,02 & 0,02 \\
\hline munkatap. négyzete & $-0,00$ & $-0,00$ & $-0,00$ & $-0,00$ & $-0,00$ \\
\hline ujbelépő & $-0,11$ & $-0,11$ & $-0,10$ & $-0,11$ & $-0,11$ \\
\hline Központi Régió & 0,14 & 0,15 & 0,15 & 0,18 & 0,17 \\
\hline Közép-, Ny.-Dunántúl & $-0,03$ & $-0,04$ & $-0,05$ & $-0,08$ & $-0,12$ \\
\hline d_legf8oszt & $-0,15$ & $-0,15$ & $-0,16$ & $-0,18$ & $-0,19$ \\
\hline d_szakiskola & $-0,06$ & $-0,06$ & $-0,06$ & $-0,09$ & 0,01 \\
\hline d_szakközépisk. & 0,17 & 0,18 & 0,17 & 0,20 & 0,24 \\
\hline d_gimnázium & 0,15 & 0,16 & 0,15 & 0,13 & 0,19 \\
\hline d_technikum & 0,32 & 0,31 & 0,30 & 0,36 & 0,34 \\
\hline d_föiskola & 0,63 & 0,63 & 0,61 & 0,75 & 0,81 \\
\hline d_egyetem & 0,79 & 0,79 & 0,77 & 0,95 & 0,98 \\
\hline d_külft*legf8oszt & 0,00 & 0,01 & 0,01 & 0,04 & 0,04 \\
\hline d_külft ${ }^{*}$ szakiskola & 0,02 & 0,02 & 0,01 & 0,04 & $-0,06$ \\
\hline d_külft ${ }^{*}$ szakközépisk. & 0,02 & 0,02 & 0,01 & $-0,01$ & $-0,04$ \\
\hline d_külft*gimnázium & 0,03 & 0,03 & 0,02 & 0,05 & $-0,04$ \\
\hline d_külft*technikum & $-0,01$ & $-0,01$ & $-0,01$ & $-0,05$ & $-0,04$ \\
\hline d_külft*föiskola & 0,19 & 0,20 & 0,19 & 0,05 & $-0,10$ \\
\hline d_külft ${ }^{*}$ egyetem & 0,16 & 0,17 & 0,17 & $-0,01$ & $-0,10$ \\
\hline 18 ágazati álváltozó & & & & & \\
\hline 11 év álváltozó & & & & & \\
\hline Konstans & 11,31 & 11,25 & 10,25 & 10,40 & 9,71 \\
\hline
\end{tabular}


Keresetek és képzettségi prémium a külföldi tulajdonú, exportáló...

\begin{tabular}{lccccc}
\hline Független változó & Összes vállalat & $\begin{array}{c}\text { Legalább 10\%-os } \\
\text { külföldi többségi } \\
\text { tulajdonhányadú } \\
\text { vállalatok }\end{array}$ & $\begin{array}{c}\text { Változóan kül- } \\
\text { vagy belföldi } \\
\text { többségi tulajdon- } \\
\text { hányadú vállalatok }\end{array}$ \\
\hline 1 & 2 & 3 & 4 & 5 & 6 \\
\hline Statisztikák & 0,57 & 0,57 & 0,60 & 0,61 & 0,62 \\
\hline$R^{2}$ & 3928402 & 3928402 & 3928402 & 2253578 & 463712 \\
\hline$N$
\end{tabular}

Megjegyzés: Az összes együttható szignifikáns egyszázalékos szinten.

A 2. (és a többi) táblázat adatainak értelmezésénél szem előtt kell tartani azt, amire az előbbiekben már utaltunk, és amit a jelölések is mutatnak: a tisztított keresetet és a független változók közül a létszámot és a termelékenységet logaritmikus formában használjuk. Ezért például a 2. oszlopban a külföldi többségi tulajdon 0,16 értékủ együtthatója azt jelenti, hogy az 17 százalékkal magasabb keresettel jár együtt.

A férfiak keresete a nőkénél 15-22 százalékkal nagyobb, a Központi Régióban a keresetek 15-19 százalékkal magasabbak, Közép- és Nyugat-Dunántúlon 3-13 százalékkal alacsonyabbak az országos átlagnál. A kétféle képzettség közül a formális képzettség fokozatai tekintélyes kereseti különbségek alapjai (a szakmunkás végzettségüek legnépesebb csoportját tekintettük alapnak, a megfelelő álváltozók együtthatói mutatják a szakmunkáskeresetektől való eltéréseket. Ami a másik fajta képzettségi mutatót, a munkában töltött éveket illeti - amelyet a következőkben munkatapasztalatnak nevezünk - ezek növekedésével nő a kereset. Az évek számának négyzete viszont negatív hatást mutat nyilvánvalóan azért, mert az aktív kor végéhez közeledve már csak lassan emelkedik, esetleg csökken a kereset. Az új belépők keresete 10-12 százalékkal kisebb annál, mint amennyi más adottságaik alapján lenne. A magasabb képzettséggel magasabb kereset jár együtt, és - a 6. oszloptól eltekintve, amelyről a következőkben külön szólunk - a föiskolai, egyetemi képzettségnek a külföldi többségi tulajdonnal is pozitív kereszthatása van.

Ahogyan azt az irodalom elemzésénél is láttuk, a külföldi többségi tulajdonlás és az értékesítési exporthányad keresetekre gyakorolt hatása függ attól, hogy milyen más magyarázó változókat használunk. A 2. oszlop szerint a külföldi többségi tulajdonnal 17 százalékkal magasabb kereset jár együtt, a harmadik oszlopban ezt már csökkenti az exporthányadhatás figyelembe vétele (amely utóbbi ott egyszázalékos 
exporthányad-emelkedésre 0,12 százalékosnak mutatkozik). Azután bekapcsoltunk az elemzésbe két további fontos tényezőt. A létszám (a létszámban mért vállalatnagyság) és a munka termelékenysége - ahogyan az az irodalom megállapításai alapján várható - pozitív hatású, és az exporttal való nyilvánvaló összefüggésük alapján figyelembe vételük - nem meglepő módon - meglehetősen csekélyre csökkenti az exportnak tulajdonítható hatást: egy százalékpont exporthányad-emelkedés csak 0,05 százalékos keresetnövekedéssel jár együtt. A többségi külföldi tulajdon pozitív kereseti hatásából pedig nyolc százalék marad.

Ugyancsak hozzáadtuk a magyarázó változókhoz a külföldi többségi tulajdon kétféle kereszthatását - más tényezővel kombinálódó hatását. A nők és férfiak keresete közötti már említett különbség (a teljes sokaságra és a nem változóan külvagy belföldi többségi tulajdonban lévő vállalatok dolgozóira vonatkozó becsléseket tartalmazó 2-4. oszlopokban) „,kiegészül” további 5-7 százalékkal - ezt mutatja a külföldi tulajdonlás és a munkavállaló neme közötti kereszthatás. A másik fontos kereszthatás a külföldi többségi tulajdonlás és a munkavállaló képzettsége között mérhető, de csak felsőfokú képzettségnél. Főiskolai és egyetemi (mester fokozatú) képzettség esetén is 17-21 százalékos kereseti többlettel jár együtt a többségi külföldi tulajdon. Más képzettségi kategóriákban nincs számottevő mértékű kereszthatás a külföldi tulajdonlással.

A táblázatban bemutatottakhoz lényegében hasonló becsléseket a vállalatok szintjén is végeztünk. Ezekben személyes helyett vállalati átlagos keresettel, átlagos korral, a nő/férfi megkülönböztetés helyett a férfi és nő dolgozók közötti aránnyal operáltunk. Az ilyen becslések azonban sem a külföldi tulajdon, sem az exportértékesítési hányad kereseti hatását tekintve nem adtak számottevő mértékben eltérő eredményeket az előbbiekhez képest, így ismertetésüktől eltekintünk.

A 2. táblázat 5. és 6. oszlopában a vállalatok két különböző részhalmazára korlátozzuk az elemzést. A két részhalmaznak fontos közös tulajdonsága az, hogy nem szerepelnek bennük olyan vállalatok, amelyekben a megfigyelt időszakban egyáltalán nem volt külföldi tulajdonhányad. Ha csak a táblázat első sorát nézzük, azt gondolhatjuk, hogy ezekben a vállalatcsoportokban a többségi külföldi tulajdon a dolgozók ugyanolyan mértékü kereseti többletével jár együtt, mint az összes vállalatban. A tüzetesebb - a külföldi többségi tulajdon kereszthatásait is figyelembe vevő - vizsgálat azonban arra a fontos megállapításra vezet, hogy az ilyen hatás ebben a két vállalatcsoportban kisebb, mint a teljes sokaságban.

A legalább 10 százalékos külfölditulajdon-hányadú vállalatok körében (5. oszlop) a magasabb szakképzettségből adódó, a többségi külföldi tulajdontól nem függő 
Keresetek és képzettségi prémium a külföldi tulajdonú, exportáló...

kereseti prémium (a szakközépiskola, de föleg a technikum, a föiskola és az egyetem esetében) lényegesen magasabb, mint a teljes sokaságban. Tehát ilyen prémium már a kisebbségi külföldi tulajdonnal is együtt jár. A többségi külföldi tulajdon keresetekre való közvetlen hatása (együtthatója) itt is ugyanúgy nyolc százalék, mint a teljes sokaságban. De valójában ezt a hatást összességében csökkenti a férfinemhez tartozás és a többségi külföldi tulajdonlás -2 százalékos kereszthatása. (Ugyanez a teljes sokaságban +5 százalék. A dolgozók többsége - a teljes sokaságban 64 , a legalább 10 százalékban külföldi tulajdonú vállalatoknál 60 százaléka - férfi.) A külföldi többségi tulajdon és a szakképzettség kereszthatása a magasabb szintek (technikum, főiskola, egyetem) esetében kevésbé pozitív vagy nagyobb mértékben negatív a legalább 10 százalékos külföldi többségi tulajdonhányadú körben, összességében lényegében kiegyenlítve az alacsonyabb képzettségi szinteken nagyobb számú dolgozónál mutatkozó kisebb, ellentétes irányú különbségeket.

A legalább 10 százalékban külföldi tulajdonú vállalatoknál megfigyeltekhez lényegében hasonló, de erősebb sajátosságokat figyelhetünk meg azon vállalatok dolgozóinak keresetalakulásában, amelyeknél a megfigyelt időszakban változás történt a belföldi/külföldi többségi tulajdonos között (6. oszlop). Ezekben az esetekben a magasabb szintủ képzettséghez kapcsolódó kereseti prémium a legfeljebb nyolc osztályt végzettek kivételével minden szinten pozitív. és a szakközépiskola, a gimnázium, a föiskola és az egyetem esetében különösen magas, tehát ezeknél a vállalatoknál a magasabb képzettség azokban az években is magasabb képzettségi prémiummal jár, amelyekben éppen nincsenek külföldi többségi tulajdonban. (Ez - persze csak átlagosan - az érintett 197 vállalat közül arra a 108-ra is érvényes, amelynél a külföldi tulajdonhányad növekvő. Ennek oka részben az, hogy a külföldi vevők gyakran olyan vállalatokat vesznek meg, amelyekben eleve viszonylag magasak a keresetek. Emellett a külföldi vevők többnyire nem egy lépésben jutnak el egy-egy vállalat többségi tulajdonához, és a keresetek már akkor is emelkednek, amikor nekik még csak kisebbségi tulajdonrészük van.) Ugyanakkor azt látjuk, hogy itt a férfinemhez tartozás és a többségi külföldi tulajdonlás kereszthatása negatív (ugyanúgy -2 az együtthatója, mint a korábban tárgyalt 10 százalék fölötti külföldi tulajdonhányadú körben). Már a szakiskolai képzettségtől kezdve jelentős (négy százaléknál nem kisebb) negatív kereszthatás mutatkozik a többségi tulajdonlás és a képzettségi mutatók között, a föiskolai és az egyetemi képzettségnél ez már 10 százalékos. Az itt tárgyalt kereszthatások egyenlege -3 százalék, tehát végső soron azt mondhatjuk, hogy ebben a körben a külföldi többségi tulajdonlásból adódó átla- 
gos kereseti többlet nem +8 (amennyit a külföldi tulajdonlás együtthatója jelezne), hanem csak +5 százalék.

3. táblázat

\section{A kereseteket befolyásoló tényezők a változó belföldi/külföldi többségi tulajdonú vállalatoknál}

(Állandó hatásos [fe] panelbecslés, 2000-2011. évi adatok alapján)

Függő változó: a tisztított kereset logaritmusa

\begin{tabular}{|c|c|c|c|c|c|}
\hline \multirow{3}{*}{ Független változó } & \multirow{2}{*}{\multicolumn{3}{|c|}{ Összes vállalat }} & Növekvő & Csökkenő \\
\hline & & & & \multicolumn{2}{|c|}{$\begin{array}{l}\text { külföldi tulajdonhányadú } \\
\text { vállalatoknál }\end{array}$} \\
\hline & 2000-2011 & $2000-2005$ & 2006-2011 & \multicolumn{2}{|c|}{ 2000-2011 } \\
\hline 1 & 2 & 3 & 4 & 5 & 6 \\
\hline külftöbbstulajdonos & 0,02 & 0,01 & 0,02 & 0,03 & $-0,01$ \\
\hline exporthányad & $-0,02$ & 0 & $-0,05$ & $-0,01$ & $-0,02$ \\
\hline ln_létszám & $-0,01$ & $-0,03$ & $-0,10$ & $-0,01$ & $-0,02$ \\
\hline ln_term_ség & 0,08 & 0,11 & $-0,01$ & 0,08 & 0,09 \\
\hline munkatapasztalat & 0,01 & 0,01 & 0 & 0,01 & 0,01 \\
\hline munkatap. négyzete & $-0,00$ & $-0,00$ & $-0,00$ & $-0,00$ & $-0,00$ \\
\hline \multicolumn{6}{|l|}{ év-álváltozók } \\
\hline konstans & 11,35 & 10,63 & 13,08 & 11,26 & 11,41 \\
\hline \multicolumn{6}{|l|}{ Statisztikák } \\
\hline$R_{-}^{2} \mathrm{~W}$ & 0,17 & 0,13 & 0,03 & 0,19 & 0,16 \\
\hline$R^{2} b_{b}$ & 0,39 & 0,37 & 0,01 & 0,34 & 0,49 \\
\hline$R^{2} \_$ & 0,23 & 0,2 & 0 & 0,25 & 0,23 \\
\hline rho & 0,33 & 0,32 & 0,4 & 0,31 & 0,36 \\
\hline sigma_u & 0,45 & 0,44 & 0,47 & 0,43 & 0,48 \\
\hline sigma_e & 0,35 & 0,36 & 0,43 & 0,34 & 0,37 \\
\hline$N$ & 463344 & 233444 & 229900 & 217407 & 243090 \\
\hline N_csoport & 202 & 186 & 161 & 108 & 89 \\
\hline
\end{tabular}


Keresetek és képzettségi prémium a külföldi tulajdonú, exportáló...

\begin{tabular}{|c|c|c|c|c|c|}
\hline \multirow{3}{*}{ Független változó } & \multirow{2}{*}{\multicolumn{3}{|c|}{ Összes vállalat }} & Növekvő & Csökkenő \\
\hline & & & & \multicolumn{2}{|c|}{$\begin{array}{c}\text { külföldi tulajdonhányadú } \\
\text { vállalatoknál }\end{array}$} \\
\hline & 2000-2011 & $2000-2005$ & 2006-2011 & \multicolumn{2}{|c|}{ 2000-2011 } \\
\hline 1 & 2 & 3 & 4 & 5 & 6 \\
\hline csop_max & 4864 & 2259 & 3763 & 1078 & 4864 \\
\hline csop_átl & 180 & 96 & 116 & 151 & 223 \\
\hline csop_min & 5 & 1 & 1 & 5 & 9 \\
\hline
\end{tabular}

Megjegyzés: A dőlt, félkövér betűs együtthatók szignifikánsak egyszázalékos szinten. Növekvö/ csökkenő tulajdonhányadú a vállalat, ha a megfigyelt időszak végén magasabb/alacsonyabb benne a külföldi tulajdon hányada, mint annak átlagában. A panelbecslés az időszak egészére, két alperiódusára és a növekvő külföldi tulajdonhányadú 108 vállalatra lényegében egységes képet ad: ezeknél a többségi külföldi tulajdon 1-3 százalékkal növeli a kereseteket. A -1 százalékos eredménnyel „kilóg” a képből a 89 csökkenő tulajdonhányadú vállalat. Ami az előbbi OLS-becsléshez való viszonyt illeti, az eltérés az ott végső soron talált +5 százalékos együtthatótól mérsékeltnek mondható: az állandó hatásos panelbecslés nem talált olyan jelentős (állandó) hatású tényezőt, amely az OLS-becslésből kimaradt volna.

Mint már utaltunk rá, a változóan külföldi vagy belföldi többségi tulajdonú vállalatok körében elemzésünk panelmódszerrel is folytatható. Az adatok gyakorisági súlyokat tartalmaznak, ezért a panelbecslésnek csak az állandó hatásos (fe) változatát tudjuk használni (a programcsomagok más lehetöséget nem adnak). Azonban az állandó hatásos becslés éppen kapóra jön nekünk. Ha ugyanis ebben sokkal kisebbnek mutatkozna a többségi külföldi tulajdon kereseti hatása, mint amit az előzőekben találtunk, az erős kételyeket támasztana a fenti eredmények iránt. Az állandó hatásos (fe) panelbecslés ugyanis, mint már utaltunk rá, a nem ismert, nem azonosítható tényezőket is beleviszi az állandó hatásba (feltéve, hogy azok állandóak). Ezzel „automatikusan” kontrollál rájuk, nem engedi, hogy hatásukat tévesen a többségi külföldi tulajdonnak tulajdonítsuk.

A panelbecslés a következő eredményeket adja. (Lásd a 3. táblázatot!)

A panelbecslés korábbiakhoz képest meglepő eredménye az exporthányad (gyönge) negatív hatása a keresetekre. Az exporthányadhatást a változó külföldi/ belföldi tulajdonú vállalatok körén túlmenően a teljes sokaságban is megvizsgálhatjuk panelmódszerrel, de természetesen csak állandó hatásos panellel, csak az időben nem állandó független változókat használva. (Lásd a 4. táblázatot!) 


\section{Az értékesítés exporthányada keresetekre gyakorolt hatásának becslése}

(Állandó hatásos [fe] panelbecslés a 2000-2011. évi adatok alapján)

Függő változó: a tisztított kereset logaritmusa

\begin{tabular}{|c|c|c|c|c|}
\hline \multirow[t]{2}{*}{ Független változó } & $\begin{array}{c}\text { Tartósan } \\
\text { exportáló válla- } \\
\text { latok }\end{array}$ & \multicolumn{3}{|c|}{ Összes vállalat } \\
\hline & $2000-2011$ & & $2000-2005$ & 2006-2011 \\
\hline 1 & 2 & 3 & 4 & 5 \\
\hline exporthányad & $-0,02$ & $-0,02$ & $-0,01$ & $-0,05$ \\
\hline ln_létszám & $-0,04$ & $-0,04$ & $-0,04$ & $-0,10$ \\
\hline ln_term_ség & 0,06 & 0,06 & 0,06 & 0,05 \\
\hline munkatapasztalat & 0,01 & 0,01 & 0,01 & 0,00 \\
\hline munkatap. négyzete & $-0,00$ & $-0,00$ & $-0,00$ & $-0,00$ \\
\hline év-álváltozók & & & & \\
\hline konstans & 11,75 & 11,69 & 10,81 & 12,15 \\
\hline Statisztikák & & & & \\
\hline$R_{-}^{2}{ }^{w}$ & 0,18 & 0,17 & 0,11 & 0,04 \\
\hline$R_{-}^{2} b$ & 0,24 & 0,31 & 0,14 & 0,01 \\
\hline$R_{-}^{2} O$ & 0,19 & 0,18 & 0,07 & 0,01 \\
\hline rho & 0,35 & 0,41 & 0,42 & 0,43 \\
\hline sigma_u & 0,43 & 0,41 & 0,39 & 0,42 \\
\hline sigma_e & 0,4 & 0,49 & 0,53 & 0,51 \\
\hline$N$ & 3153735 & 3933250 & 2088033 & 1845217 \\
\hline N_csoport & 1994 & 5798 & 4526 & 3016 \\
\hline csop_max & 7051 & 7051 & 6740 & 3763 \\
\hline csop_átl & 127 & 58 & 146 & 51 \\
\hline csop_min & 3 & 1 & 1 & 1 \\
\hline
\end{tabular}

Megjegyzés: Az összes együttható szignifikáns egyszázalékos szinten. Tartósan exportáló vállalat: az adatbázisban legalább 3 évig szereplő, az évek legalább kétharmadában exportáló vállalat. 
Keresetek és képzettségi prémium a külföldi tulajdonú, exportáló...

Az export keresetekre való hatását a 3. táblázatban bemutatott panelbecsléshez hasonlóan ez is kismértékben negatívnak mutatja, éspedig függetlenül attól, hogy „alkalmi” vagy tartósan, rendszeresen exportáló vállalatokról van-e szó. (A 20062011-es alperiódusban ez a negatív hatás erősebb, ami nyilvánvalóan összefügg a nemzetközi gazdasági válsággal.)

Panelbecsléseink tehát találnak olyan állandó hatásokat, amelyek azonosításának, figyelembe vételének hiánya az OLS-becslésekben torzítja (kis mértékben pozitívnak mutatja) az export keresetekre gyakorolt hatását.

A keresetet meghatározó tényezök hatásának idöbeli változásai

Fontos kérdés, hogy az áttekintett 2000-2011-es időszak 12 éve folyamán változtak-e, és ha igen, hogyan a kereseteket meghatározó tényezők hatásai. Az 5. táblázat - a teljes időszak adatai mellett - 2000-2001-re, 2006-2007-re, 2009-re és 2010-2011-re készített becsléseket is tartalmaz, és mindezek között kevés különbséget mutat. Az időszak kezdetéhez képest később valamelyest csökkent a többségi külföldi és az exportértékesítési hányad kereseti hatása. (Nem meglepő módon mindkettő hatása különösen alacsony volt 2009-ben, amikor nálunk a legsúlyosabb volt a nemzetközi pénzügyi válság.)

5. táblázat

\section{A keresetet meghatározó tényezők 2000-2011-ben és ennek az időszaknak néhány alperiódusában}

(OLS-becslés robusztus sztenderd hibákkal)

Függő változó: a tisztított kereset logaritmusa

\begin{tabular}{lccccc}
\hline Független változó & $\begin{array}{c}2000-2011- \\
\text { ben }\end{array}$ & $\begin{array}{c}2000-2001- \\
\text { ben }\end{array}$ & $\begin{array}{c}2006-2007- \\
\text { ben }\end{array}$ & 2009-ben & $\begin{array}{c}2010-2011- \\
\text { ben }\end{array}$ \\
\hline 1 & 2 & 3 & 4 & 5 & 6 \\
\hline külftöbbstulajdonos & $\mathbf{0 , 0 8}$ & $\mathbf{0 , 1 1}$ & $\mathbf{0 , 0 7}$ & $\mathbf{0 , 0 4}$ & $\mathbf{0 , 0 7}$ \\
nem & $\mathbf{0 , 1 5}$ & $\mathbf{0 , 1 4}$ & $\mathbf{0 , 1 7}$ & $\mathbf{0 , 1 3}$ & $\mathbf{0 , 1 7}$ \\
külftöbbs*nem & $\mathbf{0 , 0 5}$ & $\mathbf{0 , 0 1}$ & $\mathbf{0 , 0 5}$ & $\mathbf{0 , 0 9}$ & $\mathbf{0 , 0 5}$ \\
exporthányad & $\mathbf{0 , 0 5}$ & $\mathbf{0 , 0 7}$ & $\mathbf{0 , 0 5}$ & $\mathbf{0 , 0 3}$ & $\mathbf{0 , 0 5}$
\end{tabular}


Soós Károly Attila

\begin{tabular}{|c|c|c|c|c|c|}
\hline Független változó & $\begin{array}{l}2000-2011- \\
\text { ben }\end{array}$ & $\begin{array}{l}2000-2001- \\
\text { ben }\end{array}$ & $\begin{array}{l}\text { 2006-2007- } \\
\text { ben }\end{array}$ & 2009-ben & $\begin{array}{l}\text { 2010-2011- } \\
\text { ben }\end{array}$ \\
\hline 1 & 2 & 3 & 4 & 5 & 6 \\
\hline ln_létszám & 0,03 & 0,03 & 0,02 & 0,03 & 0,01 \\
\hline ln_term_ség & 0,10 & 0,10 & 0,11 & 0,10 & 0,11 \\
\hline munkatapasztalat & 0,02 & 0,02 & 0,02 & 0,02 & 0,02 \\
\hline munkatap. Négyzete & $-0,00$ & $-0,00$ & $-0,00$ & $-0,00$ & $-0,00$ \\
\hline ujbelépö & $-0,10$ & $-0,11$ & $-0,11$ & $-0,06$ & $-0,12$ \\
\hline Központi Régió & 0,15 & 0,15 & 0,13 & 0,14 & 0,14 \\
\hline Közép-, Ny.-Dunántúl & $-0,05$ & $-0,05$ & $-0,05$ & $-0,07$ & $-0,03$ \\
\hline d_legf8oszt & $-0,16$ & $-0,15$ & $-0,17$ & $-0,17$ & $-0,16$ \\
\hline d_szakiskola & $-0,06$ & $-0,06$ & $-0,06$ & $-0,04$ & $-0,03$ \\
\hline d_szakközépisk. & 0,17 & 0,17 & 0,18 & 0,20 & 0,15 \\
\hline d_gimnázium & 0,15 & 0,16 & 0,17 & 0,21 & 0,13 \\
\hline d_technikum & 0,30 & 0,31 & 0,30 & 0,32 & 0,26 \\
\hline d_föiskola & 0,61 & 0,59 & 0,62 & 0,67 & 0,61 \\
\hline d_egyetem & 0,77 & 0,75 & 0,82 & 0,78 & 0,77 \\
\hline d_külft*legf8oszt & 0,01 & $-0,00$ & 0,02 & 0,02 & 0,02 \\
\hline d_külft*szakiskola & 0,01 & 0,05 & 0,06 & $-0,07$ & $-0,04$ \\
\hline d_külft*szakközépisk. & 0,01 & $-0,01$ & 0,02 & $-0,01$ & 0,02 \\
\hline d_külft*'*imnázium & 0,02 & $-0,05$ & 0,03 & $-0,01$ & 0,06 \\
\hline d_külft*technikum & $-0,01$ & $-0,03$ & 0,00 & 0,02 & 0,04 \\
\hline d_külft*föiskola & 0,19 & 0,11 & 0,20 & 0,21 & 0,25 \\
\hline d_külft $*$ egyetem & 0,17 & 0,13 & 0,12 & 0,25 & 0,23 \\
\hline \multicolumn{6}{|l|}{18 ágazati álváltozó } \\
\hline \multicolumn{6}{|l|}{11 év-álváltozó } \\
\hline Konstans & 10,25 & 9,59 & 10,08 & 10,18 & 10,14 \\
\hline
\end{tabular}


Keresetek és képzettségi prémium a külföldi tulajdonú, exportáló...

\begin{tabular}{lrrrcrc}
\hline Független változó & $\begin{array}{c}2000-2011- \\
\text { ben }\end{array}$ & $\begin{array}{c}2000-2001- \\
\text { ben }\end{array}$ & $\begin{array}{c}2006-2007- \\
\text { ben }\end{array}$ & 2009 -ben & $\begin{array}{c}2010-2011- \\
\text { ben }\end{array}$ \\
\hline 1 & 2 & 3 & 4 & 5 & 6 \\
\hline$R^{2}$ & 0,60 & 0,46 & 0,50 & 0,53 & 0,53 \\
$N$ & 3928402 & 722684 & 627751 & 264284 & 595169 \\
\hline
\end{tabular}

Megjegyzés: A dőlt, félkövér betűs együtthatók szignifikánsak egyszázalékos szinten.

A külföldi tulajdonlás és az exportértékesités kereseti hatásai néhány ágazatban

Vizsgálódásunkat néhány ágazat szintjén is részben megismételjük. Erre a célra a textil-, a bőrfeldolgozó- és ruházati ipart választottuk, olyan ágazatokat, amelyekben - mint az irodalmi áttekintésben említettük - a magyar gazdasági átmenet kezdetén erős volt a nemzetközi termelési hálózatokba való degradáló jellegủ beilleszkedés. Az érdekel bennünket, hogy megmaradt-e valami ebből. Ugyancsak vizsgálódunk a gépiparban és azon belül külön is a közútijármü-gyártásban. Az utóbbi ágazatok kiválasztását részben az összes áruexportban játszott fontos szerepük indokolja: az elemzés tárgyát alkotó időszakban a gépipari export az összes export 70-74 százaléka között, a közútijármü-gyártás exportja az összes export 8-14 százaléka között ingadozott. Kiválasztásuk azzal is összefüggött, hogy a nemzetközi termelési hálózatokba való bekapcsolódás ezekben az ágazatokban játssza a legnagyobb szerepet. A közútijármű-gyártás exportja teljes egészében nemzetközi termelési hálózatokban való részvételként valósul meg, és a gépipar többi területén is csak szórványosan fordul elő olyan export, amely nem illeszkedik (az érintett magyar vállalatnál nagyobb külföldi vállalat által dominált) nemzetközi termelési hálózatba. Az is érdekel bennünket, hogy az ilyen bekapcsolódás pozitív vagy - a cikk irodalmat áttekintő szakaszában idézett néhány szerző várakozásainak, illetve megállapításainak megfelelően - negatív hatással van-e a keresetekre. 
6. táblázat

\section{A keresetet meghatározó tényezők becslései néhány ágazatban}

(OLS-becslés robusztus sztenderd hibákkal)

Függő változó: a tisztított kereset logaritmusa

\begin{tabular}{|c|c|c|c|c|c|}
\hline Független változó & $\begin{array}{l}\text { Összes } \\
\text { iparág }\end{array}$ & $\begin{array}{l}\text { Textil-, bőr- } \\
\text { feldolgozó és } \\
\text { ruházati ipar }\end{array}$ & $\begin{array}{l}\text { Előbbiből: } \\
\text { ruházati ipar }\end{array}$ & $\begin{array}{l}\text { Teljes gép- } \\
\text { ipar }\end{array}$ & $\begin{array}{c}\text { Előbbiböl: } \\
\text { közúti } \\
\text { jármügyártó- } \\
\text { ipar }\end{array}$ \\
\hline 1 & 2 & 3 & 4 & 5 & 6 \\
\hline külftöbbstulajdonos & 0,08 & 0,13 & 0,17 & 0,03 & 0,04 \\
\hline nem & 0,15 & 0,11 & 0,15 & 0,17 & 0,16 \\
\hline külftöbbs*nem & 0,05 & 0,03 & $-0,03$ & 0,05 & 0,06 \\
\hline exporthányad & 0,05 & 0,00 & $-0,00$ & 0,08 & 0,05 \\
\hline ln_létszám & 0,03 & 0,04 & 0,04 & 0,00 & 0,03 \\
\hline ln_term_ség & 0,10 & 0,09 & 0,03 & 0,07 & 0,12 \\
\hline munkatapasztalat & 0,02 & 0,02 & 0,01 & 0,02 & 0,02 \\
\hline munkatap. négyzete & $-0,00$ & $-0,00$ & $-0,00$ & $-0,00$ & $-0,00$ \\
\hline ujbelépö & $-0,10$ & $-0,09$ & $-0,10$ & $-0,10$ & $-0,11$ \\
\hline Központi Régió & 0,15 & 0,06 & 0,05 & 0,17 & 0,20 \\
\hline Közép-, Ny.-Dunántúl & $-0,05$ & 0,04 & $-0,02$ & $-0,05$ & $-0,12$ \\
\hline d_legf8oszt & $-0,16$ & $-0,08$ & $-0,08$ & $-0,19$ & $-0,13$ \\
\hline d_szakiskola & $-0,06$ & $-0,03$ & $-0,03$ & $-0,06$ & $-0,11$ \\
\hline d_szakközépisk. & 0,17 & 0,11 & 0,06 & 0,17 & 0,13 \\
\hline d_gimnázium & 0,15 & 0,14 & 0,14 & 0,13 & 0,11 \\
\hline d_technikum & 0,30 & 0,30 & 0,19 & 0,31 & 0,26 \\
\hline d_föiskola & 0,61 & 0,53 & 0,34 & 0,64 & 0,67 \\
\hline d_egyetem & 0,77 & 0,57 & 0,60 & 0,79 & 0,91 \\
\hline$d_{-} k \ddot{u} l f t * l e g f 8 o s z t$ & 0,01 & $-0,01$ & $-0,01$ & 0,06 & 0,02 \\
\hline d_külft* ${ }_{\text {szakiskola }}$ & 0,01 & $-0,03$ & $-0,01$ & $-0,00$ & 0,09 \\
\hline d_külft ${ }^{*}$ szakközépisk. & 0,01 & 0,08 & 0,09 & 0,01 & 0,02 \\
\hline
\end{tabular}


Keresetek és képzettségi prémium a külföldi tulajdonú, exportáló...

\begin{tabular}{|c|c|c|c|c|c|}
\hline Független változó & $\begin{array}{l}\text { Összes } \\
\text { iparág }\end{array}$ & $\begin{array}{l}\text { Textil-, bör- } \\
\text { feldolgozó és } \\
\text { ruházati ipar }\end{array}$ & $\begin{array}{l}\text { Elöbbiből: } \\
\text { ruházati ipar }\end{array}$ & $\begin{array}{l}\text { Teljes gép- } \\
\text { ipar }\end{array}$ & $\begin{array}{c}\text { Elöbbiböl: } \\
\text { közúti } \\
\text { járműgyártó- } \\
\text { ipar }\end{array}$ \\
\hline 1 & 2 & 3 & 4 & 5 & 6 \\
\hline d_külft*gimnázium & 0,02 & 0,03 & $-0,01$ & 0,03 & 0,04 \\
\hline d_külft*technikum & $-0,01$ & $-0,04$ & 0,07 & $-0,01$ & 0,02 \\
\hline d_külft ${ }^{*}$ föiskola & 0,19 & 0,19 & 0,31 & 0,21 & 0,15 \\
\hline d_külft $*$ egyetem & 0,17 & 0,22 & 0,36 & 0,22 & 0,07 \\
\hline \multicolumn{6}{|l|}{18 ágazati álváltozó } \\
\hline \multicolumn{6}{|l|}{11 év-álváltozó } \\
\hline Konstans & 10,25 & 10,11 & 10,83 & 10,64 & 9,99 \\
\hline \multicolumn{6}{|l|}{ Statisztikák } \\
\hline$R^{2}$ & 0,60 & 0,53 & 0,54 & 0,57 & 0,57 \\
\hline$N$ & 3928402 & 250208 & 84232 & 1719845 & 353778 \\
\hline
\end{tabular}

Megjegyzés: A dőlt, félkövér betűs együtthatók szignifikánsak egyszázalékos szinten.

A becslési eredményeket a 6 . táblázat mutatja. A külföldi többségi tulajdonlás mindegyik ágazatcsoportban erősen szignifikáns pozitív hatással van a keresetekre. Többnyire az exportértékesítési hányad hatása is pozitívnak mutatkozik. A kivétel - a ruházati iparban megfigyelhető csekély negatív hatás - a külföldi tulajdonlás különösen erős pozitív hatásával párosul.

A textil-, a bőrfeldolgozó és a ruházati iparban és külön a ruházati iparban a külföldi többségi tulajdon és a legfeljebb nyolcosztályos végzettség csupán csekély mértékủ negatív kereszthatását figyelhetjük meg. A külföldi többségi tulajdon és a nem kereszthatása 3, illetve -3 százalékos; az összes ágazat átlagához képest mindkét esetben a nők járnak jól. Így végül is azt mondhatjuk, hogy most már nem találjuk nyomát a kiszolgáltatott (főleg női) munkaerő olcsó bérért való foglalkoztatásának, a külföldi vállalatok által megszervezett „,bérmunkáztatásának”, amely a ruházati iparban a rendszerváltás körül nálunk is elterjedt volt.

A külföldi többségi tulajdon pozitív kereseti hatása a gépiparban és a közútijármü-gyártásban az átlagosnál kisebb mértékủ. Ezt részben kompenzálja a többségi külföldi tulajdon és a férfinemhez tartozás magasabb kereszthatása, emellett (több- 
ségi tulajdontól függetlenül) technikumtól felfelé a képzettségi prémiumok is viszonylag magasak ezekben az ágazatokban. A gépiparon belül a közútijármü-gyártás az a terület, ahol a legnagyobb arányú a nemzetközi termelési láncokban való részvétel, és így - az irodalmi áttekintésben idézett néhány szerző gondolatmenetét követve - talán a legnagyobbnak gondolhatjuk azt a veszélyt, hogy a magyar munkaerő degradáló jellegü alávetettségbe kerül a termelési láncokat szervező külföldi vállalatokkal szemben, ezért a kereseteket lefelé nyomó hatás érvényesül. Becslési eredményeink szerint azonban az ágazatban nemcsak a többségi külföldi tulajdon, hanem az exportértékesítési részarány is pozitív hatással van a keresetekre, és semmilyen más hatásban (beleértve a kereszthatásokat) sem látjuk semmilyen jelét annak, hogy a közútijármü-gyártás külgazdasági nyitottsága negatív hatást gyakorolna a dolgozók kereseteire.

\section{Következtetések}

A magyar 2000-2011. évi feldolgozóipari adatok alapján vizsgáltuk ökonometriai eszközökkel a vállalatok többségi külföldi tulajdonlásának és exportértékesítésének hatását dolgozóik keresetére.

- A vállalatok teljes körében vizsgálódva és kontrollálva egyéb fontos tényezőkre - a vállalati létszámra, a munka vállalati szintü termelékenységére, az exportra, az ország régiói közötti általános kereseti különbségekre, a dolgozók nemére, szakképzettségére, munkatapasztalatára, továbbá arra, hogy vállalatánál a dolgozó új belépő-e, valamint az ágazatok és az évek közötti általános kereseti különbségekre - azt találtuk, hogy a többségi külföldi tulajdon a dolgozók 8 százalékos kereseti többletét vonja maga után. Emellett itt a többségi külföldi tulajdonnal (kereszthatásként) nagyobb a férfinemhez tartozással, valamint a főiskolai, egyetemi végzettséggel járó keresleti többlet. Az ágazati szintű elemzés is pozitív kereseti hatást mutat azokon a területeken, amelyeken az irodalomban található bizonyos elemzések (részben inkább elöítéletek) alapján leginkább számítani lehetne a külföldi tulajdonlás kedvezőtlen kereseti hatására. Nevezetesen a ruházati iparról és a közútijármü-gyártásról, valamint az összevontan megvizsgált textil-ruházati és bőrfeldolgozó iparról, illetve gépiparról van szó. A gépiparban és azon belül a közútijármü-gyártásban a nemzetközi termelési láncokban való részvétel keresetekre gyakorolt pozitív hatását figyeltük meg. 
Keresetek és képzettségi prémium a külföldi tulajdonú, exportáló...

- Vizsgálódásunkat azon vállalatok körében külön is elvégeztük, amelyekben megfigyelésük éveiben mindig volt legalább 10 százalékos külföldi tulajdon. Ebben a körben a magasabb szakképzettségből adódó, a többségi külföldi tulajdontól nem függő kereseti prémium (a szakközépiskola, de főleg a technikum, a föiskola és az egyetem esetében) lényegesen nagyobb, mint a teljes sokaságban. Tehát ilyen prémium már a kisebbségi külföldi tulajdonból is fakad. A többségi külföldi tulajdon keresetekre való közvetlen hatása (együtthatója) e körben is ugyanúgy nyolc százalék, mint a teljes sokaságban. De valójában ezt az utóbbi hatást összességében csökkenti a férfinemhez tartozás és a többségi külföldi tulajdonlás -2 százalékos kereszthatása. (Ugyanez a teljes sokaságban +5 százalék. A dolgozók többsége - a teljes sokaságban 64, a legalább 10 százalékban külföldi tulajdonú vállalatoknál 60 százalékban - férfi.) A külföldi többségi tulajdon és a szakképzettség kereszthatása a magasabb szintek (a technikum, a föiskola, az egyetem esetében) kevésbé pozitív vagy nagyobb mértékben negatív a legalább 10 százalékos külföldi tulajdonhányadú körben, összességében lényegében kiegyenlíti az alacsonyabb képzettségi szinteken nagyobb számú dolgozónál mutatkozó kisebb, ellentétes irányú különbségeket.

- Elemzésünk egy másik szükített körét azok a vállalatok (azon vállalatok dolgozói) alkották, amelyeknél a vizsgált időszak egy részében belföldi, más részében külföldi volt a többségi tulajdonos (közülük 108-nál volt növekvő, 89-nél csökkenő a külföldi tulajdonhányad). A legalább 10 százalékban külföldi tulajdonú vállalatoknál megfigyeltekhez lényegében hasonló, de erősebb sajátosságokat figyelhettünk meg ezeknél. Közöttük a magasabb szintủ képzettséghez kapcsolódó kereseti prémium a legfeljebb nyolc osztályt végzettek kivételével minden szinten pozitív és a szakközépiskola, a gimnázium, a föiskola és az egyetem esetében különösen magas, tehát ezeknél a vállalatoknál a magasabb képzettség azokban az években is magas képzettségi prémiummal jár, amelyekben éppen nincsenek külföldi többségi tulajdonban. Ugyanakkor azt látjuk, hogy itt a férfinemhez tartozás és a többségi külföldi tulajdonlás kereszthatása negatív (ugyanúgy -2 az együtthatója, mint a 10 százalék fölötti külföldi tulajdonhányadú körben). Emellett már a szakiskolai képzettségtől kezdve jelentős (négy százaléknál nem kisebb) negatív kereszthatás mutatkozik a többségi tulajdonlás és a képzettségi mutatók között - a föiskolai, egyetemi képzettségnél ez már 10 százalékos. Mindezek a kereszthatások csökkentik a többségi külföldi tulajdon együtt- 
hatójában mutatkozó kereseti többletet, egyenlegük -3 százalék, tehát végső soron azt mondhatjuk, hogy ebben a körben a külföldi többségi tulajdonlásból adódó átlagos kereseti többlet nem +8 (ennyi az együttható), hanem csak +5 százalék.

- Az utóbbi vállalatoknál a külföldi többségi tulajdon keresetekre gyakorolt hatását az OLS-becslés mellett állandó hatásos panelbecsléssel is meg tudtuk vizsgálni. Az ilyen becslés „automatikusan” kontrollál az olyan tényezők hatására, amelyek a megfigyelt időszakon belül állandóak, akkor is, ha ezeket a tényezőket nem tudjuk azonosítani, számszerűsíteni, akár nem is tudunk róluk. Panelbecslésünk szerint a többségi külföldi tulajdon 1-3 százalékkal növeli a kereseteket. Ami az előbbi OLS-becsléshez való viszonyt illeti, az eltérés az ott végső soron talált +5 százalékos együtthatótól mérsékeltnek mondható: az állandó hatásos panelbecslés nem talált olyan jelentős (állandó) hatású tényezőt, amely az OLS-becslésből kimaradt volna. A kétféle becslés jóval kisebb mértékủ összefüggést mutat a külföldi többségi tulajdon és a keresetek között annál, amit Earle-Telegdy [2008] közel egy évtizeddel korábbi periódusra, 1992-2003-ra talált. Náluk OLS-becsléssel a mi 8 százalékos koefficiensünk négyszerese adódott, amely fix hatásos panelbecsléssel körülbelül a felére csökkent.

- Az exportértékesítési hányad keresetekre gyakorolt hatását is vizsgáltuk mind OLS-, mind panelbecsléssel. OLS-sel különböző specifikációkban egy százalékpont exportértékesítési hányadra 0,05 százalékos kereseti különbség adódott, a megfigyelt időszakon belül csökkenő tendenciával. Az állandó hatásos panelbecslésben (amelyet itt a teljes sokaságra el tudtunk végezni, emellett külön elvégeztünk a tartósan exportáló vállalatokra is) azonban ez eltủnt: az exportértékesítési hányad hatásaként csekély $-0,02$ negatív érték adódott. Tehát itt a panelbecslés eredménye valamivel nagyobb mértékü, de ugyancsak negatív irányú eltérést mutat az OLS-becsléstől, mint a többségi külföldi tulajdon hatásának mérésénél. 
Keresetek és képzettségi prémium a külföldi tulajdonú, exportáló...

\section{Hivatkozások}

Akerlof, G. A. - Yellen, J. L. [1986]: Introduction. In: Akerlof, G. A. - Yellen, J. L. (eds.): Efficiency Wage Models of the Labor Market. Cambridge University Press, Cambridge, 1-21. o.

Alfaro, L. - Charlton, A. [2009]: Intra-Industry Foreign Direct Investment. American Economic Review, Vol. 99., No. 5., 2096-2119. o.

Amiti, M. - Davis, D. R. [2011]: Trade, Firms, and Wages: Theory and Evidence. Review of Economic Studies, Vol. 79., No. 1., 1-36. o.

Anner, M. [2011]: The Impact of International Outsourcing on Unionization and Wages: Evidence From the Apparel Export Sector in Central America. Industrial and Labor Relations Review, Vol. 64., No. 2., 305-322. o.

Aturupane, C. - Djankov, S. - Hoekman, B. [1999]: Horizontal and Vertical Intra-industry Trade between Eastern Europe and the European Union. Weltwirtschaftliches Archiv/Review-of WorldEconomics, Vol. 135., No. 1., 62-81. o.

Aydiner-Avsar, N. [2014]: Revisiting the Trade-Wage Structure Nexus: A Micro Analysis for Turkey. The Journal of Development Studies, Vol. 50., No. 8., 1156-1171. o.

[2012]: Temporary trade and heterogeneous firms. Journal of International Economics, Vol. 87., No. 2., 232-246. o.

Braunstein, E. - Brenner, M. [2007]: Foreign Direct Investment and Gendered Wages in Urban China. Feminist Economics, Vol. 13., No. 3-4., 213-237. o.

Breau, S. - Brown, W. M. [2011]: Exporting, Foreign Direct Investment, and Wages: Evidence from the Canadian Manufacturing Sector. Growth and Change, Vol. 42., No. 3., 261-286. o.

Brown, C. - Hamilton, J. - Medoff, J. [1990]: Employers Large and Small. Cambridge, MA, Harvard University Press.

Brown, D. K. - Deardorff, A. V. - Stern, R. M. [2003]. The Effects of Multinational Production On Wages and Working Conditions In Developing Countries. NBER Working Paper, No. 9669.

Carluccio, J. - Fougere, D. - Gautier, E. [2014] Trade, Wages and Collective Bargaining: Evidence From France. Banque de France Working Paper, No. 498. Letölthetö: https://papers.ssrn.com/sol3/ papers.cfm?abstract_id $=2469169$.

Damijan, J. P. - Kostevc, C. [2011]: Trade Liberalisation and Economic Geography In CEE Countries: the Role of FDI in the Adjustment Pattern of Regional Wages. Post-Communist Economies, Vol. 23., No. 2., 163-89. o.

Earle, J. S. - Telegdy, A. [2008]: Ownership and Wages: New Evidence from Linked EmployerEmployee Data in Hungary, 1986-2003. In: Bender, S. - Lane, J. - Shaw, K. - Andersson, F. - von Wachter, T. (eds.): The Analysis of Firms and Employees. Quantitative and Qualitative Approaches, Cambridge MA, NBER, 229-252. o.

Egger, P. - Stehrer, R. [2001]: International Outsourcing and the Skill-Specific Wage Bill in Eastern Europe. WIFO Working Papers, No. 151, WIFO, München.

Egger, H. -Egger, P. - Keickemeier, U. - Moser, C. [2015]: The Exporter Wage Premium When Firms and Workers are Heterogeneous. CEPIE Working Paper, No. 12/17.

Feliciano, Z. M. - Lipsey, R. E. [2006]: Foreign Ownership, Wages, and Wage Changes in U.S. Industries, 1987-92. Contemporary Economic Policy, Vol. 24., No. 1., 74-91. o.

Fertö, I. - Soós, K. A. [2009]: Duration of trade of former communist countries in the EU market. PostCommunist Economies, Vol. 21., No. 1., 31-39. o.

Gabrisch, H. - Werner, K. [1998]: Advantages and drawbacks of EU membership - the structural dimension. Comparative Economic Studies, Vol. 40., No. 3., 79-103. o.

Gelübcke, W. - Philipp, J. [2013]: Foreign ownership and firm performance in German services. Service Industries Journal, Vol. 33., No. 15/16., 1564-1598. o. 
Girma, S. - Greenaway, D. - Wakelin, K. [2001]: Who Benefits from Foreign Direct Investment in the UK? Scottish Journal of Political Economy, Vol. 60., No. 5., 560-574. o.

Globerman, S. - Ries, J. C. - Vertinsky, I. [1994]: The economic performance of foreign affiliates in Canada. The Canadian Journal of Economics, Vol. 27., No. 1., 143-156. o.

Greaney, T. M. $-L i, Y$. [2013]: Trade, Foreign Direct Investment and Wage Inequality in China: A Heterogeneous Firms Approach. China Economic Policy Review, Vol. 2., No. 2., 1-49. o.

Hale, G. - Long, C. [2013]: Did Foreign Direct Investment Put an Upward Pressure on Wages in China? IMF Economic Review, Vol. 59., No. 3., 404-430. o.

Helpman, E. - Itskhoki, O. - Redding, S. [2010]: Inequality and Unemployment in a Global Economy. Econometrica, Vol. 78., No. 4., 1239-1283. o.

Heyman, F. - Sjöholm, F.- Tingvall, P. G. [2007]: Is there Really a Foreign Ownership Wage Premium? Evidence from Matched Employer-Employee Data. Journal of International Economics, Vol. 73., No. 2., 355-376. o.

Hosein, R. - Tewarie, B. [2005]: Globalisation, Increased FDI Flows and Wage Inequality in a Small, Petroleum-Rich Economy. West Indian Journal of Engineering, Vol. 27., No. 2., 1-24. o.

Hunya, G. [2014]: Regional Policy and FDI Location - An Overview of The Larger New EU Member States. GRINCOH Working Paper Series, Paper No. 2.13. Letölthető: http://www.grincoh.eu/ media/serie_2_international_economic_relations/grincoh_wp2.13_hunya.pdf.

Kalleberg, A. L. - Van Buren, M. E. [1996]: Is Bigger Better? Explaining the Relationship Between Organization Size and Job Rewards. American Sociological Review, Vol. 61., No. 1., 47-66. o.

Kézdi, G. [2002]: Two Phases of Labor Market Transition in Hungary: Inter-Sectoral Reallocation and Skill-Biased Technological Change. Budapest Working Paper Series on the Labour Market, No. $2002 / 3$.

Kyoji, F. - Murakami, Y. [2005]: Do Foreign Firms Bring Greater Total Factor Productivity to Japan? Journal of the Asia Pacific Economy, Vol. 10., No. 2., 237-254. o.

Lazear, E. P. - Moore, R. L. [1984]: Incentives, Productivity, and Labor Contracts. The Quarterly Journal of Economics, Vol. 99., No. 3., 275-296. o.

Lipsey, R. E. - Sjöholm, F. [2004]: Foreign Direct Investment, Education and Wages In Indonesian Manufacturing. Journal of Development Economics, Vol. 73., No. 1., 415-422. o.

Lipsey, R. E. - Sjöholm, F. [2006]: Foreign Firms and Indonesian Manufacturing Wages: An Analysis with Panel Data. Economic Development - Cultural Change, Vol. 55., No. 1., 201-21. o.

Lorentowicz, A. - Marin, D. - Raubold, A. [2005]: Is Human Capital Losing from Outsourcing? Evidence for Austria and Poland. CESifo Working Paper, No. 1616. CESifo, Munich.

Macis, M. - Schivardi, F. [2016]: Exports and Wages: Rent Sharing, Workforce Composition, or Returns to Skills? Journal of Labor Economics, Vol. 34., No. 4., 945-978. o.

Milner, C. - Tandrayen, V. [2007]: The Impact of Exporting and Export Destination on Manufacturing Wages: Evidence for Sub-Saharan Africa. Review of Development Economics, Vol. 11., No. 1., 13-30. o.

Mincer, J. [1958]: Investment in Human Capital and Personal Income Distribution. Journal of Political Economy, Vol. 66., No. 4., 281-302. o.

Peluffo, A. [2001]: Foreign Direct Investment, Productivity, Demand for Skilled Labour and Wage Inequality: An Analysis of Uruguay. The World Economy, Vol. 38., No. 6., 962-998. o.

Rankin, N. - Schöer, V. [2013]: Export Destination, Product Quality and Wages in a Middle-Income Country. The Case of South Africa. Review of Development Economics, Vol. 17., No. 1., 64-73. o.

Reizer, B. [2017]: Wage structure, employment and efficiency. Letölthetö: https://editorialexpress.com/ cgi-bin/conference/download.cgi?db_name=EEAESEM2017\&paper_id $=556$

Tomohara, A. - Yokota, K. [2011]: Foreign direct investment and wage inequality: is skill upgrading the culprit? Applied Economics Letters, No. 18., 773-781. o. 
Villarreal, A. - Sakamoto, A. [2011]: Bringing the firms into globalization research: The effects of foreign investment and exports on wages in Mexican manufacturing firms. Social Science Research, Vol. 40., No. 3., 885-901. o.

$W u, X$. [2001]: Foreign direct investment, intellectual property rights, and wage inequality in China. China Economic Review, Vol. 11., No. 2., 361-384. o.

Zhang, X. - Zhang, K. H. [2003]: How Does Globalisation Affect Regional Inequality Within a Developing Country? Evidence from China. The Journal of Development Studies, Vol. 39., No. 4., 47-67. o.

Zhao, Y. [2001]: Foreign Direct Investment and Relative Wages: the Case of China. China Economic Review, Vol. 12., No. 1., 40-57. o.

Zulfiu-Alili, M. [2014]: Inward Foreign Direct Investment and Wage Inequality in Macedonia. Eastern European Economics, Vol. 52., No. 5., 56-86. o. 